\title{
Matching Local and Global Dimensions: A Knowledge Based Approach to Classify European Life Sciences Clusters
}

\author{
Adele Parmentola ${ }^{1}$ \\ ${ }^{1}$ Department of Management and Quantitative Studies, Università degli studi di Napoli Parthenope \\ Correspondence: Adele Parmentola, Associate Professor at Department of Management and Quantitative \\ Studies, Università degli Studi di Napoli Parthenope, Via Generale Parisi, 13, 80132, Napoli, Italy. E-mail: \\ adeleparmentola@gmail.com; adele.parmentola@uniparthenope.it
}

Received: June 21, 2017

doi:10.5539/ijbm.v12n9p17

\author{
Accepted: July 24, 2017 \\ Online Published: August 12, 2017 \\ URL: https://doi.org/10.5539/ijbm.v12n9p17
}

\begin{abstract}
It is now widely accepted that innovation is a territorially embedded process, which cannot be fully understood independent of the social and institutional conditions of individual places. On the basis of these considerations, some authors identified criteria to define the geographic confines for the innovative process, introducing the concept of the local systems of innovation (LIS), defined as networks of technologically specialized and locally situated firms, institutions and research agencies. Nevertheless empirical evidences show that especially in high tech industry like life sciences, relatively few clusters are completely self-sufficient in terms of the knowledge base from which they draw suggesting that the knowledge flows that feed innovation in a cluster are often both local and global.

According to these considerations and starting from the knowledge based theory of innovations systems the paper proposes a theoretical framework that classifies the innovation systems considering the place of knowledge sourcing and the place of knowledge development. The framework has then been used to classify the European life sciences clusters. The empirical analysis shows that Local Innovation System is only a possible configuration of technology clusters that can be assumes also the configurations of Imported Innovation Systems, Exported Innovation Systems and Global Innovation Systems.
\end{abstract}

Keywords: innovation systems, local systems, global knowledge, life science industry, Europe

\section{JEL: O30}

\section{Introduction}

Some authors underline as the phenomenon of the globalization of the world market have increased and not reduced the importance of the characteristics of local context as driver of the firms 'competitive advantage. Actually the Regionalisation, defined as the dependence of economic activities on resources that are specific to individual places, is regarded as an aspect of economic globalisation because some innovative, regional clusters are key nodes in the increasingly globalised arena of production. The principal empirical sign of the trend towards regionalisation is the apparent growth in importance of regional clusters and innovation systems over the last decades. Since the 1970s different types of regional cluster have established a strong position in world markets for both traditional products (e.g. Third Italy) and high technology products (e.g. Silicon Valley).

At the same time some authors have defined the generation of innovation as a local embedded process in which the firm collaborates with other actors, such as research agencies and government institutions, in both developmental and implementation phases (Fagerberg, 2004). This observation concerning institutions, and the consideration that geographic proximity permits role-players to interact more easily, quickly led to a realisation of the importance of the territorial variable in stimulating development of innovation (Lundvall \& Johnson 1994; Etzkowitz \& Leyedsdorff, 2000). On the basis of these considerations, some authors identified criteria to define the geographic confines for the innovative process, introducing the concept of the "national innovation system" (NIS) (Freeman, 1987), "regional innovation system" (RIS), (Doloreux, 2002) and of local systems of innovation (LIS)(Cooke 2001, 2004; Asheim \& Coenen, 2005).

Nevertheless empirical evidences show that especially in high tech industry like life sciences relatively few clusters are completely self-sufficient in terms of the knowledge base from which they draw. The development of 
ever more complex technologies requires the support of sophisticated organizational networks that provide key elements or components of the overall technology (Kash \& Rycroft, 2000). While some elements of these complex technologies may be co-located in an individual cluster, increasingly the components of these networks are situated across a wide array of locations. This suggests that the knowledge flows that feed innovation in a cluster are often both local and global (Bathelt et al., 2004).

According to these considerations and starting from the knowledge based theory of innovations systems the paper aims at exploring the combination of local and global dimensions of innovations systems proposing a theoretical framework that classifies the innovation systems considering the place of knowledge sourcing and the place of knowledge development.

The framework has then been used to classify the European life sciences clusters.

The paper will be organised as follows: the section 2 presents a short review of the studies of the knowledge based theory of innovation systems summarising both the traditional approaches and the more recent studies on global knowledge flows; the section 3 presents the original framework; the section 4 shows the application of the framework to the European Life Sciences Clusters; the section 4 summarizes the papers' conclusions.

\section{The Knowledge Based Theory of Innovation Systems: Theoretical Background}

\subsection{The Importance of Local Dimension}

It is now widely accepted that innovation is a territorially embedded process, which cannot be fully understood independent of the social and institutional conditions of individual places (Lundvall, 1992; Asheim, 1999). The "territorially embedded" factors influencing the innovation process have thus become the focus for a number of theoretical perspectives: from that of the innovative milieu (Camagni, 1995) and industrial district (Becattini, 1987) to those of the learning region (Morgan, 1997) and innovation system (Cooke et al., 1997; Cooke, 1998).

These approaches offer powerful insights that help improve our understanding of how and under what conditions the innovation process takes place. Some of the most relevant findings deriving from these approaches concern the significance of territorial proximity, local synergies, and interaction (Camagni, 1995, p. 317), and the importance of local inter-organisation networks, financial and legal institutions, technical agencies, research infrastructures, education and training systems, governance structures and innovation policies (Iammarino, 2005, p. 499) in shaping innovation.

The central argument of these approaches is that the joint production and transmission of new knowledge occurs most effectively among economic actors located close to each other. . A fundamental determinant for innovationm generation is precisely geographic proximity. There are several researches that show how spillover knowledge is geographically focused and studies in favor of geographical proximity as possible determinant of collaborations (Feldman, 1994; Hong \& Yu-Sung Su, 2012; Henderson, Jaffe, \& Trajtenberg, 1998; Adams, 2002; Anselin, Varga, \& Acs, 2000; Rodriguez-Pose \& Crescenzi, 2008). Proximity to critical sources of knowledge, whether they are found in public or private research institutions or embeddedin the core competencies of lead or anchor firms, facilitates the process of acquiring new technical knowledge, especially when the relevant knowledge is located at the research frontier or involves a largely tacit dimension.

Such interactions stimulate the transmission of knowledge in the form of knowledge spillovers (Jaffe, 1986; Acs et al., 1992) that are reaped by the same local actors.

On the other hand the potential for knowledge spillovers to traverse national and regional borders depends on the nature of the knowledge concerned (Leamer and Storper, 2001)

Geographic proximity is a key mechanism especially because it allows the transfer and diffusion of knowledge through face-to-face interactions or direct interactions between researchers (Bishop, D'este, and Neely, 2011). There are studies that support the importance of geographic proximity as an easy means to convey an important component of knowledge, namely, tacit knowledge (Howell, 2002, Storper and Venables, 2004). This theme is directly related to the subject of Morgan (2004) "person-embodied" knowledge, since direct interaction between individuals is needed to develop and disseminate knowledge (Abramovsky, Harrison, \& Simpson, 2007). Explicit knowledge is coded and transmitted through formal and systematic language (Spender, 1996); While tacit knowledge is personal, context specific and, as such, difficult to formalize and communicate. It can only be shared through field experience (Bartezzaghi, 2010; Nonaka, Negata, \& Toyama, 2000). A similar definition proposed by Maskell and Malmberg (1999, p. 172) is summarized as "tacit knowledge can only be producted in practice."

In an attempt to elaborate further the role that knowledge plays in sustaining clusters, Maskell (2001) has 
proposed a knowledge-based theory of the cluster. In particular Maskell states that geographic proximity facilitates the increase of knowledge through horizontal and vertical processes. Horizontally because system actors have easier access to sources of knowledge. Vertical because it stimulates a process of imitation from the bottom that increases the demand of knowledge. (Maskell 2001,

In general, the importance and advantages of local collaboration (geographical proximity) are widely recognized in the literature (Abramovsky, Harrison, \& Simpson, 2007; Storper \& Venables, 2004) but Howell (2002) argues that geographic proximity acts indirectly (indirect role) and is neither a necessary condition nor a sufficient condition for a successful collaboration. The author argues that by playing an indirect role, proximity still positively influences university collaborations and the exchange of knowledge between the two organizations. Boshma (2005) also questions the importance of physical proximity "for itself", arguing that geographic proximity must always be examined in relation to other forms of proximity. It refers to social, organizational, institutional and cognitive proximity. In fact, according to Howell, (2002) the author argues: "In sum, the geographical proximity may facilitate inter-organizational learning, but it is neither a necessary nor a sufficient condition." (Pag71)

Proximity not only understood from a geographic point of view, but understood as an organizational proximity.

In other words, the degree to which firms can tap into a common knowledge base at the local level depends on more than just spatial proximity, cultural affinity or corporate culture. In this sense there is a strong interdependence between the economic structure and social institutions that comprise the cluster. (Gertler, 2003; 2004; Breschi \& Malerba, 2001).

According to these some scholar have focused their analysis on geograohical boundaries of innovation process distinguishing among national, regional and local innovation systesms. With specific regard to National Innovation Systems (NIS), scholars emphasise four main components (Freeman, 1987): (i)the role of policy, (ii) the role of corporate research and development (R\&D) in accumulating knowledge and developing advantages from it; (iii) the role of human capital, the organization of work and the development of related capabilities, (iv) the role of industrial conglomerates in being able to profit from innovations emerging from developments along the entire industrial value chain, and three main "building blocks" (Lundvall, 1992): (i) Sources of Innovation (Learning and Search and exploration); (ii) Types of Innovation (Radical vs. Incremental); (iii) Non-market institutions (User-Producer Interactions and Institutions) and set-up of actors (especially universities conducting R\&D) (Nelson, 1998). Finally, Soete et al (2010) emphasised the role of Social Capital (most importantly trust) in the interactive innovation processes.

Scholars of geographic economy (Asheim et al., 2011; Edquist, 1997), starting from the assumption of the non-homogeneity within countries as many indicators can differ significantly in the areas of the same countries, developed a regionally based approach of innovation systems. Doloreux and Parto (2005), identify three main domensions that characterise the Regional Innovation Systems: (i) the interactions between the actors of the innovation system in relation to the exchange of knowledge; (ii) the set - up and the role of institutions supporting knowledge exchange and innovation within a region; (iii) the role of RIS in regional innovation policy - making.

Nevertheless, in more recent years, several scholars began to question the advantages of considering regions as the fundamental geographic entity for describing the localised nature of innovation systems, As a consequence they applied the term Local Innovation System, to define a network of locally specialised and locally situated firms, institutions and research agencies that are involved in a process of collective learning, where this process is not limited to geographical borders (Cooke, 2001, 2004; Asheim \& Coenen, 2005).

A knowledge-based theory of the cluster must recognize that relatively few clusters are completely self-sufficient in terms of the knowledge base from which they draw. Territories also have capacities to attract and assimilate innovation that has been produced elsewhere. The origin of knowledge spillovers can be local, but they can also be generated outside the borders of the locality or region object of the analysis, as "there is no reason that knowledge should stop spilling over just because of borders, such as a city limit, state line or national boundary" (Audretsch \& Feldman, 2004, p. 6).

As consequence many authors have undelined the necessity to overcome the local dimension analysing the importance of glocal knowledge flows for innovation systems development.

\subsection{Overcoming the Local Dimension and the Importance of the Global Knowledge Flows}

The territorial dimension of knowledge relations and their multilevel character matter for learning and innovation in clusters. Whereas geographical and institutional proximities at the local and regional levels support 
the exchange of tacit knowledge and interactive learning, selective knowledge links with firms and research organisations at the international and global levels contribute complementary and specialised, often codified, knowledge assets (Bathelt et al., 2004). Innovative cluster firms tend to be both well embedded in the regional innovation system and well connected to partners and networks of production, distribution, R\&D, and knowledge exchange at international and global levels (Archibugi \& Lundvall, 2001).

Accordingly, recent studies have pointed to the multi-level and multi-scalar nature of knowledge relations in the innovation process and that it is it is rare that innovation dynamics unfold on one spatial scale (Kash \& Rycroft 2000;-Asheim et al. 2011, Tödtling \& Tripp, 2013).

Bathelt et al. (2004) affirm that successful clusters are those that are effective at building and managing a variety of channels for accessing relevant knowledge from around the globe mixing local and global knowledge flows, using the authors term mixing local buzz and global pipelines. Local buzz refers to knowledge and inspiration that circulate between the actors of a cluster. This buzz consists of specific information flows, knowledge transfers and continuous updates as well as opportunities for learning in organised and spontaneous meetings (see, particularly, Bathelt et al., 2004; Storper \& Venables 2004). Buzz is the force that facilitates the circulation of information in a local economy or community and it is also the mechanism that supports the functioning of networks in the community. Pipelines, on the other hand, refer to channels of communication used in distant interaction, between firms in clusters and knowledge-producing centres located at a distance. As Bathelt et al. (2004) suggest both local buzz (the knowledge and communication ecology created by co-location of relevant actors) and global pipelines (channels used in accessing knowledge external to a region) offer advantages for organisations engaged in innovation and knowledge creation. They push their definition further by maintaining that 'local buzz is beneficial to innovation processes because it generates opportunities for a variety of spontaneous and unanticipated situations, global pipelines are instead associated with the integration of multiple selection environments that open different potentialities and feed local interpretation and usage of knowledge hitherto residing elsewhere' (Bathelt et al., 2004).There is increasing evidence to suggest that even in the most advanced clusters, a growing proportion of the knowledge base is not exclusively local but it is transferred form abroad trough a mechanism defined glocal pipeline.. Pipelines that are external channel that open the cluster to other territory and support the acquisition of external knowledge and the diffusion of information within the cluster (Owen-Smith \& Powell, 2004). This stimulates additional buzz and serves as a basis for further product innovation and differentiation. Without the buzz, however, the pipelines are of little use because they predefine and, in part, restrict the way in which new knowledge is applied. Local buzz in a cluster enables firms to isolate those elements that are particularly important for the further development of technologies and to discard those with little prospect of success from the mass of external information available. This saves both time and money and speeds up innovation processes.

The most dynamic of multinational corporations and a larger proportion of emerging small and medium-sized enterprises have strong linkages to a variety of specialized clusters around the globe. Both types of firms use their presence in these local clusters to access specialized bodies of knowledge created by the local research institutions, or to tap into a specialized skill set or knowledge base developed by cluster-based firms.(Gertler \& Wolfe, 2006)

Hence, local interaction and global pipelines can be perfectly complementary as sources of innovation (Bathelt et al., 2004; Maskell et al., 2006). On the one hand, local interaction both in its formal and in its more informal 'buzz' dimension contributes

to making individual firms more innovative, often through small incremental innovations and the generation of synthetic knowledge. On the other hand, global pipelines channel analytical and radical new knowledge which helps firms to introduce more radical innovations (Moodysson et al., 2008). These innovations are later diffused locally through interaction. As Maskell et al (2006, page 1007) indicate, "when one firm [in the cluster] is successful, the result, or parts of the applied knowledge, will sooner or later leak out to the firm's nearby competitors" (Sotarauta et al., 2011, 200).

Coherently to what affirmed by the literature the concept of innovation system must be redefined to include also the global dimension. Coherently a new classification of innovation systems has been proposed in the following paragraph.

\section{A New Framework of Innovation Systems: Combining Local and International Knowledge}

Coherently to what affirmed in the previous section empirical evidences show how in many industry there are innovation systems that combine the local dimension with an international dimension. 
In many countries indeed the creation of innovation systems requires an injection of foreign knowledge which successively has been exploited in a specific territory. On the other hand there are cases where the local produced knowledge must be exploited in the foreign markets.

Coherently a new classification of innovation systems has been proposed that considers two dimensions:

- Knowledge Sourcing: this dimension analyses where the knowledge is developed by firms or universities if inside or outside the innovation system's geographical boundary.

- Knowledge Development: this dimension analyses where knowledge is exploited by firms if inside or outside the innovation system's geographical boundary.

Combining these two dimensions we obtain four kinds of innovation systems:

- Local Innovation Systems: it is the classical configuration described by the literature where the knowledge has origin and it is developed in a specific territory thanks to cooperation among local universities, firms and institutions:

- Imported Innovation Systems: are systems that are developed in a specific territory thanks to the knowledge developed abroad and imported in the system. These systems are characterised by a strong collaboration with foreign firms and research organizations that are often encouraged to open a branch in the territory.

- Exported Innovation Systems: are systems where the knowledge is create in a specific geographical location thanks to cooperation among local universities, firms and institutions but it is exploited abroad. It is the case for example of the creation of satellite clusters thanks to the internationalisation of large multinationals that need to go abroad because the local context it's too small to obtain enough economic results.

- Global Innovation Systems: are systems where the knowledge has origin and it is developed in a global context thanks to cooperation among universities, firms and institutions located in different territories. In this case the system is not linked to the local dimension and the actors are connected by global knowledge flows.

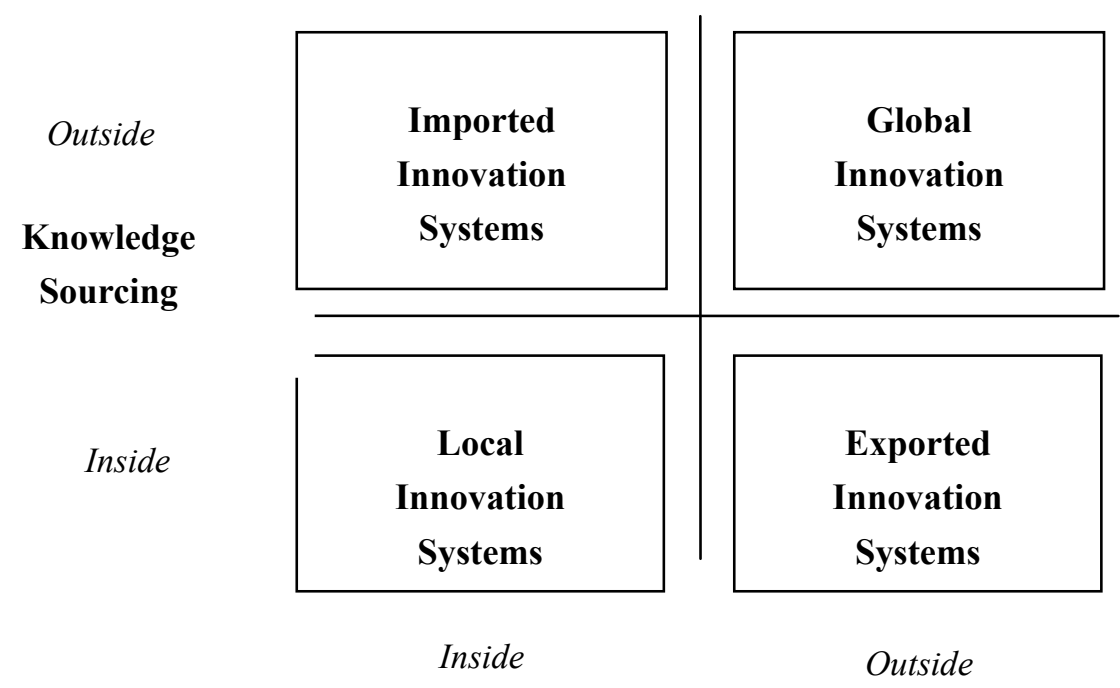

Knowledge Development

Figure 1. Original framework: classification of innovation systems

The described model is then used to classify the EU life sciences clusters. Life sciences industry indeed is characterized by a high pressure toward innovation that requires high investments in R\&D and constant relationships among firms and research institutions. These latter aspects and the explicit nature of the knowledge developed create an increasing tension toward globalization of local systems.

\section{Empirical Analysis: Classification of EU Life-Sciences Innovation Systems}

Life science industry includes biotechnology, pharmaceutical and medical instruments sectors and it is one of the most important industry considering both the rate of innovation and the financial performance. (Deloitte report, 2016). 
Today the dimension of the EU life science industry are comparable with the dimension of the US one. European policy makers indeed have long been actively promoting the growth and expansion of Life Science industries, driven by factors such as the increasing life expectancy of the aging European population and the general aim to improve living standards of the population. Growth has been further spurred by technological progress in related sectors, which has allowed new research and development opportunities.

The total number of Life Science companies is 10,737, across 14 European countries and Israel. The greatest concentration is in Germany at 1,876, closely followed by the UK at 1,610 and France at 1,112. For Biotech companies it is the same pattern with Germany at 1,042, the UK at 979 and France at 720 , while at the other end of the spectrum, Austria (94), Ireland and Finland (82 each) and Ireland (65) have the fewest.

For Medtech, Germany again leads the way with 572 companies, then Sweden (301), while those with the fewest are Norway (32), Finland (37) and Ireland (39).

The Pharma industry is largest in the UK with 110 companies being based there, next is Germany with 103 and France with 94 . The country with the most employees in LS is Germany $(247,000)$, followed by the UK $(174,000)$ then France $(146,000)$.

The largest focus area of products is oncology, especially in the leaders countries as Germany, the UK, Switzerland and France, where oncology predominates.

There are some interesting exceptions such as Austria's focus in early development on infectious diseases, while Belgium focuses more on diseases of the musculoskeletal system and connective tissue. Other product area Products are concentrated in late in Ireland center on cardiovascular diseases and in Spain, Finland and the Netherlands on the central nervous system.

Coherently with what is happened in other territories also EU life-sciences industry is showing important changes, from one hand the activities are often territorially based and concentrated in a number of local innovation systems, on the other hand we observe a high level of openness of actors of the existing cluster to global market.

In particular Germany and the UK have the highest number of global Headquartes (HQs) of domestic LS companies, followed by France and Switzerland. (KPMG report, 2016).

Differences among European regions do not are related only to the specialization and to the dimension of the clusters located in the different regions Clusters can be formed at a variety of levels: they can be concentrated in a city, they can spread across borders, they can be the result of a national strategy to boost innovation. It is also the case that depending on their audience, clusters may like to present themselves as independent clusters in their own right, or on other occasions to be seen as part of a larger entity. In the UK, for example, Cambridge is promoted both as the area around the city and also as part of the 'Golden Triangle' of Cambridge, Oxford and London.

France is a champion in multiplying its innovation nodes. Areas covered by umbrella organizations such as Lyonbiopole or Medicen, which are defined as clusters, contain within them multiple sub-groups, labelled as "clusters" by the French state. The city of Oslo counts no less than 11 life sciences clusters.

Moreover clusters present also different capacity to attract foreign companies. According to KPMG report, there are three types of European countries: countries with strong clusters of life science companies and an attractive tax and business environment; countries that have significant clusters of life science companies in their jurisdictions, but lack the benefits of an attractive business environment; countries which have attractive business and tax regimes without the support of a strong domestic biopharmaceutical industry.

Accordingly we start from the Sanofi report of the EU leading life science clusters to classify them accordingly to the framework presented in the paper (Kelly et al, 2016).

The study, commissioned by Sanofi, covers 17 geographical areas that fit a common preliminary criterion: they form a coherent structure where universities, research labs, science parks, incubators, hospitals, start-ups, large companies and government agencies cooperate, with the joint aim of generating innovation. They also respond to a national, regional or local strategy to join forces with the objective of strengthening the area's competitiveness and economic growth. 


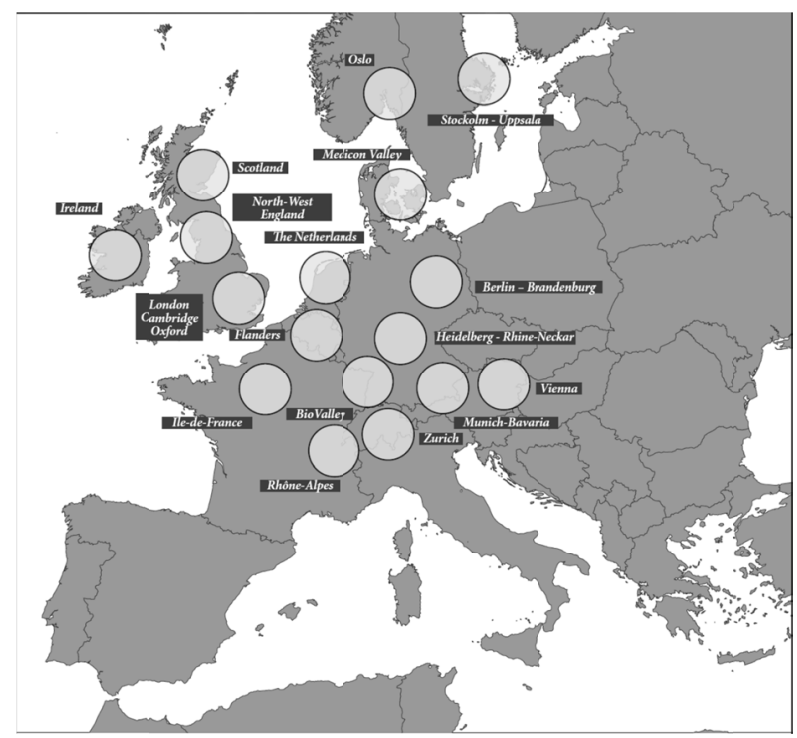

Figure 2. Map of EU life sciences clusters

Source: Kelly E., Zubascu F., O’Dea J., Cracea R., and Madde D. (2016), Leading life sciences clusters in Europe, Study Commisioned by Sanofi. Leading Science|Business Publishing Ltd Avenue des Nerviens 79, Box 22, 1040 Brussels, Belgium.

The data are collected using the secondary sources as report, cluster website, articles.

Each cluster has been considered as a single unit of analysis and an in-deep investigation is conducted to explore factors like initial location, innovation activity, inbound and outbound internationalization of systems' actors, policies implemented by local institutions, presence of inter-systems alliances. To evaluate if the knowledge sourcing and development activities are inside or outside the systems 'boundaries we consider the nationality of both the universities and the companies and their role in the learning process.

We graduate the systems considering the level of knowledge sourcing and knowledge development on a scale from 1 to 100 and we consequently build a map that classifies the EU life sciences clusters. The dimension of the circles indicates the geographical extension of the clusters in squares kilometers (see figure 4).

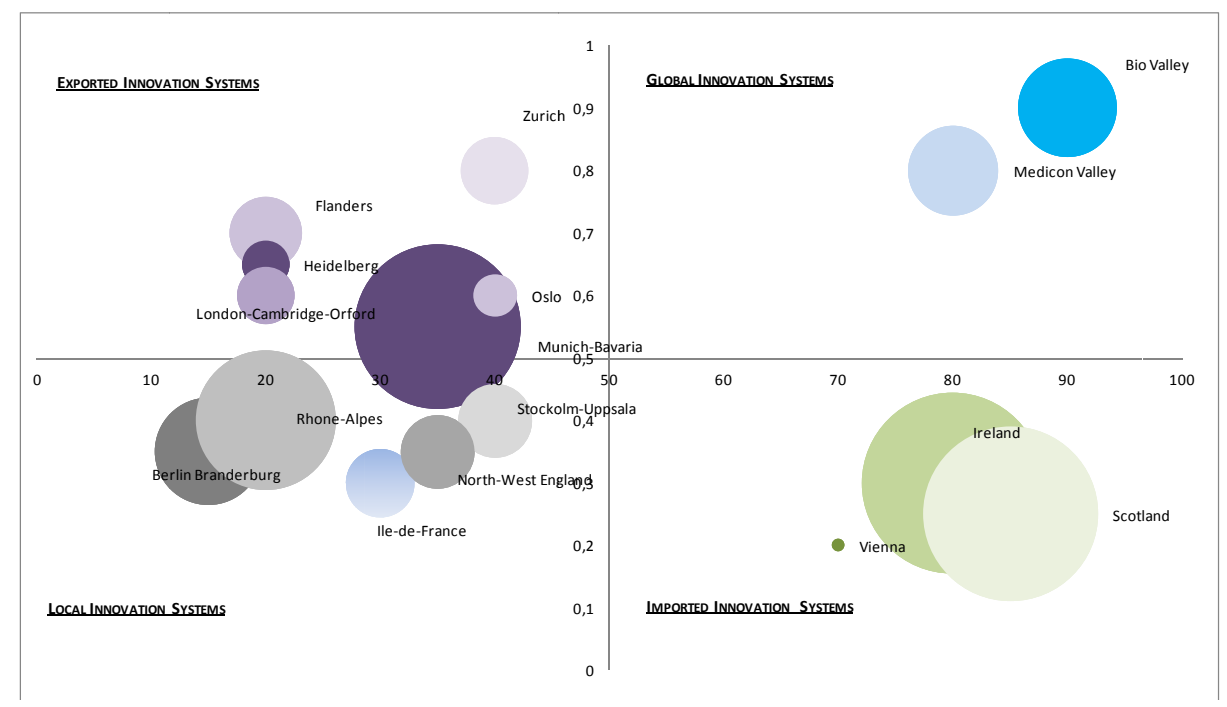

Figure 4. Classification of EU life sciences clusters

Many EU clusters present the configuration of traditional Local Innovation Systems where the knowledge is created and exploited in a specific region. Usually this category includes the most ancient clusters like 
Stockolm-Uppsala in Sweden and the Manchester cluster (North-West England) in UK. Large part of EU clusters present an increasing tension toward globalisation, the knowledge is developed in a specific territory thanks to cooperation of one or few local universities and public research centres but it is exploited also abroad trough the internationalisation of local companies and the links with clusters situated in other countries. It is for example the case of the UK Golden Triangle (London- Cambridge- Oxford) where the local companies have constant collaborations with US pharmaceutical MNEs. It is also the case of the Zurich clusters where are located many biotech and pharmaceutical companies that concentrate their R\&D activities in Zurich but need to go abroad or create foreign alliances to exploit their knowledge and to obtain enough economic returns also for the limited geographical dimensions of the original areas.

In EU there are also some Imported Innovation Systems like the Scotland, Ireland and Vienna clusters. These systems are often young and are created trough the specific initiatives of local governments. Usually in these territories there is a lack of a strong knowledge tradition in life sciences industry that the government tries to overcome creating fiscal and economic incentives for foreign life-sciences companies that want to open R\&D branches in the territory or encourage cooperation with foreign universities. It is the case for example of the Vienna cluster the youngest and the smallest of the EU life sciences systems.

Finally in EU there are present two Global Innovation Systems: the Medicon Valley and the Bio Valley.

These two clusters are born linked universities and firms of different EU states and present a strong global tension. In particular the Bio Valley consists of 14 technology research parks situate in the middle of Europe in a region at the centre of Switzerland, Germany and France. Bio Valley is the home of 40 per cent of the world's leading pharmaceutical companies like Novartis and Roche. These companies have their home in the Valley but have their branches in biotech clusters all over the world. The global tension regards also the universities indeed there is a plan to create a European university campus in the border region of Germany, France and Switzerland.

Medicon Valley instead is localised in the North Europe and include some 11 universities and many firms of Sweden and Denmark. The cluster is created as a global system and manifests also today a strong global tension especially thanks to their large companies like Novo Nordisk.

\section{Conclusions}

It is now widely accepted that innovation is a territorially embedded process, which cannot be fully understood independent of the social and institutional conditions of individual places (Lundvall, 1992; Asheim, 1999). On the basis of these considerations, some authors identified criteria to define the geographic confines for the innovative process, introducing the concept of the local systems of innovation (LIS), defined as networks of technologically specialized and locally situated firms, institutions and research agencies (Cooke 2001, 2004; Asheim and Coenen 2005). Nevertheless empirical evidences show that especially in high tech industry like life sciences, relatively few clusters are completely self-sufficient in terms of the knowledge base from which they draw suggesting that the knowledge flows that feed innovation in a cluster are often both local and global. Bathelt et al. (2004).

According to these considerations and starting from the knowledge based theory of innovations systems the paper proposes a theoretical framework that classifies the innovation systems considering the place of knowledge sourcing and the place of knowledge development. Our paper shows that local innovation systems is only one of the possible configuration of technology clusters that can be assumes also the configurations of Imported Innovation Systems, Exported Innovation Systems and Global Innovation Systems.

The application of the framework to the European life-sciences clusters shows that in Europe are present all the configurations of the systems.

The paper has interesting theoretical and practical implications. From the theoretical point of view the paper suggests an original framework that enlarges the concept of innovation systems proposed by the literature introducing new configuration more adapt to represents the reality. The proposed framework could be applied by other scholars to analyse the innovation systems in other geographical regions or in other industries. From the practical point of view the paper encourages the policy makers to rethink their strategies too locally centred emphasizing also the opportunities stemming by a global view of the phenomenon and by collaboration with other nations.

Despite these strengths the paper is a first approach to the topic and the theoretical framework could benefit by further improvements and applications. 


\section{References}

Abramovsky, L., Harrison, R., \& Simpson, H. (2007). University Research and the Location of Business R\&D. The Economic Journal, 114-142. https://doi.org/10.1111/j.1468-0297.2007.02038.x

Acs, Z., Audretsch, D., \& Feldman, M. (1992). Real Effects of Academic Research: A Comment. American Economic Review, 82, 363-367.

Adams, J. D. (2002). Comparative localization of academic and industrial spillovers. Journal of Economic Geography, 2(3), 253-278. https://doi.org/10.1093/jeg/2.3.253

Adams, J. D., \& Jaffe, A. B. (2002). Bounding the effects of R\&D: an investigation using matched firm and establishment data. Rand Journal of Economics, 27, 700-721. https://doi.org/10.2307/2555878

Anselin, L., Varga A., \& Acs, Z. (1997). Local Geographic Spillovers Between University Research and High Technology Innovations,Journal of Urban Economics, 42, 422-448. https://doi.org/10.1006/juec.1997.2032

Asheim, B. T., Smith, H. L., \& Oughton, C. (2011). Regional innovation systems: theory, empirics and policy. Regional Studies, 45(7), 875-891. https://doi.org/10.1080/00343404.2011.596701

Asheim, B., \& Coenen, L. (2005). Knowledge bases and regional innovation systems: Comparing Nordic clusters. Research Policy, 34, 1173-1190. https://doi.org/10.1016/j.respol.2005.03.013

Audretsch, D. B., \& Feldman, M. P. (2004). Knowledge spillovers and the geography of innovation. Handbook of Regional and Urban Economics, 4, 2713-2739. https://doi.org/10.1016/S1574-0080(04)80018-X

Bartezzaghi, E. (2010). L'organizzazione dell'Impresa. Milano: ETAS.

Bathelt, H., Malmberg, A., \& Maskell, P. (2004). Clusters and knowledge: local buzz, global pipelines and the process of knowledge creation. Progress in Human Geography, 28(1), 31-56. https://doi.org/10.1191/0309132504ph469oa

Becattini, G. (1987). Mercato e forze locali: il distretto industriale. Il Mulino, Bologna.

Bishop, K., D'este, P., \& Neely, A. (2011). Gaining from interactions with universities: Multiple methods for nurturing. Research Policy, 40(1), 30-40. https://doi.org/10.1016/j.respol.2010.09.009

Boschma, R. (2005). Proximity and Innovation: A Critical Assessment. Regional Studies, 39(1), 61-74. https://doi.org/10.1080/0034340052000320887

Breschi, S., and Malerba, F. (2001). The geography of innovation and economic clustering: Some introductory notes. Industrial and corporate change, 10(4), 817-833. https://doi.org/10.1093/icc/10.4.817

Camagni R. (1995) The Concept of Innovative Milieu and its Relevance For Public Policies in European Lagging Regions, Regional Science, 74(4), 317-340. https://doi.org/10.1111/j.1435-5597.1995.tb00644.x

Charlot, S., \& Duranton, G. (2006). Cities and workplace communication: some quantitative French evidence. Urban Studies, 43(8), 1365-1394. https://doi.org/10.1080/00420980600776459

Cooke, P. (1998). Introduction. Origins of the concept. In Braczyk, H. J. et. al. (Eds.), Regional Innovation Systems (pp. 2-25). UCL Press, London. https://doi.org/10.1007/978-1-4471-3985-0_1

Cooke, P. (2001), Regional innovation systems, clusters, and the knowledge economy. Industrial and Corporate Change, 10(4), 945-974. https://doi.org/10.1093/icc/10.4.945

Cooke, P. (2004). The role of research in regional innovation systems: New models meeting knowledge economy demands. International Journal of Technology Management, 28(3-6), 507-533. https://doi.org/10.1504/IJTM.2004.005307

Cooke, P., Uranga M. G., \& Etxebarria, G. (1997). Regional innovation systems: Institutional and Organisational dimensions. Research Policy, 26, 475-491. https://doi.org/10.1016/S0048-7333(97)00025-5

Deloitte. (2016), Global life sciences outlook. Moving forward with caution optimism. Report 2016.

Doloreux, D. (2002). What we should know about regional systems of innovation? Technology in Society: An International Journal, 24, 243-263. https://doi.org/10.1016/S0160-791X(02)00007-6

Doloreux, D., \& Parto, S. (2004). Regional innovation systems: a critical synthesis. Institute for New Technologies, United Nations University.

Edquist, C. (1997). Systems of innovation: technologies, institutions and organizations. London: Pinter.

Etzkowitz, H., \& Leydesdorff, L. A. (2000). The dynamics of innovation: from national systems and "mode 2" to 
a triple helix of university-industry-government relations. Research Policy, 29, 109-123. https://doi.org/10.1016/S0048-7333(99)00055-4

Fagerberg J. (2004). Innovation: A Guide to the Literature, in Fagerberg, J., Mowery, D., Nelson, R. (Eds.), The Oxford Handbook of Innovation (pp. 291-317). Oxford University Press, Oxford.

Feldman, P. (1994). The Geography of Innovation. Amsterdam: Kluwer. https://doi.org/10.1007/978-94-017-3333-5

Freeman, C. (1987). Technology and economic performance: lessons from Japan. London: Pinter.

Gertler M. (2003). Tacit Knowledge and the Economic Geography of Context, of The Undefinable Tacitness of Being (There). Journal of Economic Geography, 3, 75-99. https://doi.org/10.1093/jeg/3.1.75

Gertler, M. S. (2004). Manufacturing culture: The institutional geography of industrial practice. Oxford University Press.

Gertler, M. S., \& Levitte, Y. M. (2005). Local nodes in global networks: the geography of knowledge flows in biotechnology innovation. Industry and Innovation, 12(4), 487-507. https://doi.org/10.1080/13662710500361981

Gertler, M. S., \& Wolfe, D. A. (2006). Spaces of knowledge flows: Clusters in a global context. Clusters and regional development: Critical reflections and explorations, 218-235.

Henderson, R., Jaffe, A., \& Trajtenberg, M. (1998). Universities as a source of commercial technology a detailed analysis of university patenting. MIT Press Journal, 80(1), 119-127.

Hendry, C., Brown, J., \& Defillippi, R. (2000). Regional clustering of high technology-based firms:

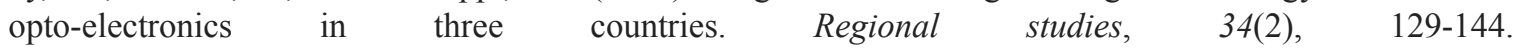
https://doi.org/10.1080/00343400050006050

Hong, W., \& Su, Y. S. (2012). The effect of institutional proximity in non-local university-industry collaborations: An analysis based on Chinese patent data. Research Policy, 1-11.

Howell, J. (2002). Tacit Knowledge, Innovation and Economic Geography. Sage Publications, 39(5-6), 871-884. https://doi.org/10.1080/00420980220128354

Iammarino, S. (2005) An Evolutionary Integrated View of Regional Systems, Measures And Historical Perspectives. European Planning Studies, 13(4), 497-519. https://doi.org/10.1080/09654310500107084

Jaffe, A. B. (1986). Technological Opportunity and Spillovers of R\&D:Evidence from Firms' Patents, Profits, and Market Value. The American Economic Review, 76, 984-1001.

Kelly, E., Zubascu, F., O’Dea, J., Cracea, R., \& Madde, D. (2016). Leading life sciences clusters in Europe, Study Commisioned by Sanofi. Leading Science|Business Publishing Ltd Avenue des Nerviens 79, Box 22, 1040 Brussels, Belgium.

KPMG. (2016). Site selection for life sciences companies in Europe., June 2016, www.kpmg.ch/siteselection

Leamer, E., \& Storper, M. (2001). The economic geography of the Internet age, Journal of International Business Studies, 32(4), 641-666. https://doi.org/10.1057/palgrave.jibs.84909988

Lundvall, B. A. (1992). National systems of innovation: towards a theory of innovation and interactive learning. London: Pinter.

Lundvall, B. Å., \& Archibugi, D. (Eds.). (2001). The globalizing learning economy. New York: Oxford University Press.

Lundvall, B. A., \& Johnson, B. (1994). The learning economy. Journal of Industry Studies, 1(2), 23-42. https://doi.org/10.1080/13662719400000002

Maskell, P. (2001). Towards a knowledge - based theory of the geographical cluster. Industrial and corporate change, 10(4), 921-943. https://doi.org/10.1093/icc/10.4.921

Maskell, P., \& Malmberg, A. (1999). Localized learning and industrial competitiveness. Cambridge Journal of Economics, 23, 167-186. https://doi.org/10.1093/cje/23.2.167

Moodysson, J., Coenen, L., \& Asheim, B. (2008). Explaining spatial patterns of innovation: analytical and synthetic modes of knowledge creation in the Medicon Valley life-science cluster. Environment and planning A, 40(5), 1040-1056. https://doi.org/10.1068/a39110

Morgan, K. (1997). The learning region: institutions, innovation and regional renewal.Regional Studies 31: 
491-504. https://doi.org/10.1080/00343409750132289

Morgan, K. (2004). The exaggerated death of geography: learning, proximity and territorial innovation systems. Journal of Economic Geography, 4, 3-21. https://doi.org/10.1093/jeg/4.1.3

Nelson, R. (1993). National systems of innovation: a comparative study. New York: Oxford University Press.

Nonaka, I., Negata, A., \& Toyama, R. (2000). A firm as a knowledge-creating entity: a new perspective on the theory of the firm. Industrial and Corporate Change, 9, 1-20. https://doi.org/10.1093/icc/9.1.1

Owen-Smith, J., \& Powell, W. W. (2004). Knowledge networks as channels and conduits: The effects of spillovers in the Boston biotechnology community. Organization Science, 15(1), 5-21. https://doi.org/10.1287/orsc.1030.0054

Pisano, G. P. (1990). The R\&D Boundaries of the Firm. An empirical. Administrative Science Quarterly, 35, 153-176. https://doi.org/10.2307/2393554

Polanyi, M. (1966). The Tacit Dimension. New York: Doubleday.

Rodriguez-Pose, A., \& Crescenzi, R. (2008). Research and Development, Spillovers, Innovation Systems, and the Genesis of Regional Growth in Europe. Regional Studies, 42(1), 51-67. https://doi.org/10.1080/00343400701654186

Rycroft, R. W., \& Kash, D. E. (2000). Steering complex innovation. Research-Technology Management, 43(3), $18-23$.

Soete, L., Verspagen, B., and Ter Weel, B. (2010). Systems of innovation. Handbook of the economics of innovation, 2, 1159-1180. https://doi.org/10.1016/S0169-7218(10)02011-3

Sotarauta, M., Ramstedt-Sen, T., Kaisa Seppänen, S., \& Kosonen, K. J. (2011). Local or digital buzz, global or national pipelines: patterns of knowledge sourcing in intelligent machinery and digital content services in Finland. European Planning Studies, 19(7), 1305-1330. https://doi.org/10.1080/09654313.2011.573139

Spender, J. C. (1996). Making Knowledge the basis of a dynamic theory of the firm. Strategic Management Journal, 17, 45-62. https://doi.org/10.1002/smj.4250171106

Storper, M., \& Venables, A. J. (2004) Buzz: face-to-face contact and the urban economy. Journal of EconomicGeography, 4, 351-370. https://doi.org/10.1093/jnlecg/lbh027

Strambach, S., and Klement, B. (2012). Cumulative and combinatorial micro-dynamics of knowledge: The role of space and place in knowledge integration. European Planning Studies, 20(11), 1843-1866. https://doi.org/10.1080/09654313.2012.723424

Sturgeon, T. J. (2003). What really goes on in Silicon Valley? Spatial clustering and dispersal in modular production networks. Journal of economic geography, 3(2), 199-225. https://doi.org/10.1093/jeg/3.2.199

Todtling, F., \& Kaufmann, A. (1999). Innovation Systems in Regions in Europe -- A Comparative Perspective, European Planning Studies, 7, 699-717. https://doi.org/10.1080/09654319908720549

Tödtling, F., \& Trippl, M. (2013). 14 Transformation of regional innovation systems. Re-Framing Regional Development: Evolution, Innovation, And Transition, 62, 297.

\section{Copyrights}

Copyright for this article is retained by the author(s), with first publication rights granted to the journal.

This is an open-access article distributed under the terms and conditions of the Creative Commons Attribution license (http://creativecommons.org/licenses/by/4.0/). 